\title{
A Novel Metaphor Concerning the Terminology of Open Innovation
}

\author{
Shanta Rajapaksha Yapa ${ }^{1}$, R Senathiraja ${ }^{1} \&$ Ilkka Kauranen ${ }^{2}$ \\ ${ }^{1}$ Faculty of Management \& Finance, University of Colombo, Sri Lanka \\ ${ }^{2}$ Department of Industrial Engineering \& Management, Aalto University, Finland \\ Correspondence: Shanta Rajapaksha Yapa, Faculty of Management \& Finance, University of Colombo, Sri \\ Lanka. E-mail: shantayapa@gmail.com
}

Received: December 18, 2020

Accepted: January 26, 2021

Online Published: January 27, 2021

doi:10.5539/ibr.v14n2p114

URL: https://doi.org/10.5539/ibr.v14n2p114

\begin{abstract}
The objective of this article is to present a metaphor concerning the terminology of open innovation. This metaphor will help both academics and practitioners in getting a deeper understanding of the terms and their relationships in this emerging field. An electrical circuit is used as the metaphor. In it, the following open innovation terms are included: inbound open innovation, outbound open innovation, sequential coherence, dynamic innovation capabilities, knowledge flow, absorptive capacity, organizational inertia, and innovation performance. A corresponding term for each one of these open innovation terms is given in the metaphor. Within an organization, open innovation involves the internal exploration of external knowledge and external exploitation of internal knowledge. Open innovation is gaining wide attention of researchers as it impacts innovation performance of organizations. Systematic metaphor analysis is a qualitative research method. A metaphor is an implicit comparison in which a word or phrase that originally denotes a certain object or concept is applied to another. Time tested relationships among variables in the metaphor of electric circuit offer new insights in the domain of open innovation.
\end{abstract}

Keywords: inbound open innovation, outbound open innovation, sequential coherence, dynamic innovation capabilities, knowledge flow, absorptive capacity, organizational inertia, and innovation performance

\section{Introduction}

Open innovation is emerging as an increasingly important paradigm for technological innovation success (Kim et al., 2016). Openness has become a trend in innovation management (Lopez \& Carvalho, 2018). Openness of firms across the world enabled the mankind to fight against the deadly COVID 19 pandemic by leveraging human and physical capital fast (Chesbrough, 2020). Business firms of all sizes and in diverse industry sectors are increasingly engaging in open innovation to promote innovations (Yapa \& Senathiraja, 2017). Although the practices of open innovation and related academic discussions existed before, it was Chesbrough (2003) who introduced the umbrella term open innovation. Researchers are debating the nature of the open innovation paradigm, attempting to understand its determinants (Lazzarotti et al., 2017) and how open innovation activities positively or negatively affect success, which is measured in various different ways (Hossain \& Kauranen, 2016).

Open innovation is both a multi-faceted phenomenon (Randhawa et al., 2016) and a multi-level phenomenon (Bogers et al., 2017). Open innovation literature continues to grow at an increasing speed. The number of open innovation-related terms is increasing, many of the terms are overlapping, and some definitions are inconsistent. All this increases the complexity of the terms and their relationships. There is a need to clarify the situation.

\section{The Objective of the Article}

The objective of this article is to present a metaphor concerning the terminology of open innovation. This metaphor will help both academics and practitioners in getting a deeper understanding of the terms and their relationships in this emerging field. An electrical circuit is used as the metaphor and the following open innovation terms are included: inbound open innovation, outbound open innovation, sequential coherence, dynamic innovation capabilities, knowledge flow, absorptive capacity, organizational inertia, and innovation performance. A corresponding term for each one of these open innovation terms is given in the metaphor. This new metaphor is significant to open innovation research in three ways. Firstly, to our best of knowledge this is the first ever published metaphor in the open innovation domain. If not, this must still be one of the early 
attempts. Secondly, our metaphor is unique as it uses natural science phenomena to explain a social science phenomenon. Thirdly, we anticipate that effective use of a metaphor will attract future researchers to use metaphors in theory development and the analysis of complex social systems.

\section{What Is Open Innovation?}

Open innovation is understood as the systematic encouragement and exploration of a wide range of internal and external sources of innovative opportunities, the integration of this exploration with firm capabilities and resources, and the exploitation of these opportunities through multiple channels (West \& Gallagher, 2006). Participating in open innovation using inflows and outflows of knowledge has become an important premise for a successful organization (Sekliuckiene et al., 2016). Open innovation is in receipt of wide attention of academics as it seems to have a significant impact on organizational performance (Kim et al., 2015; Chesbrough \& Tucci, 2020) as a winning strategy (Ahn et al., 2016). The benefits of open innovation include sales growth (Rubera et al., 2016; Cheng \& Huizingh, 2014; Chaston, 2013), increased competitiveness (Al-Belushi et al., 2015), a decrease in production costs (Noh, 2015), higher invention quality (Walsh et al., 2016), and employee job satisfaction (Lee et al., 2014). In order to improve innovation performance, firms are increasingly acquiring technological knowledge from external sources, a key strategic approach in open innovation (Bianchi et al., 2015).

\section{What Is a Metaphor?}

A metaphor is defined as a word or phrase applied to an object or concept that it does not literally denote in order to make a comparison with the other object or concept under consideration (Ortony, 1979). Metaphors are especially useful in understanding concepts in social science and theory development (Hunt \& Menon, 1995). Systematic metaphor analysis is considered as a method of qualitative research (Schmitt, 2005). Scholars and practitioners rely on metaphors to gain a deeper understanding of various domains (Morgan \& Reichert, 1999). Metaphors may not provide a perfect fit to the actual situation being analyzed. In order to reap the benefits, the use of metaphors can offer, one should not concentrate on judging the suitability of a metaphor. Instead, one should try to examine the metaphor to see hitherto unseen perspectives on the problem or situation being analyzed. Metaphors can be used to perform a variety of analyses (Palmer \& Dunford, 1996) as they can facilitate and further our understanding (Cornelissen et al., 2008), trigger new avenues for analysis, and surface new relationships. As regards to terms and their relationships in a field, metaphors have the power to connect various terms together in order to illuminate the big picture.

\section{A Novel Metaphor}

In our metaphor, an open innovation system corresponds to an electrical circuit. With this metaphor, we can easily connect and understand important regularly-used terms in the open innovation domain by thinking through the metaphor.

In accordance to the objective of this study, a novel metaphor concerning the terminology of open innovation is presented in Figure 1. An electrical circuit is used in the metaphor. The regularly used open innovation terms namely inbound open innovation, outbound open innovation, sequential coherence, dynamic innovation capabilities, knowledge flow, absorptive capacity, and organizational inertia are included in the metaphor.

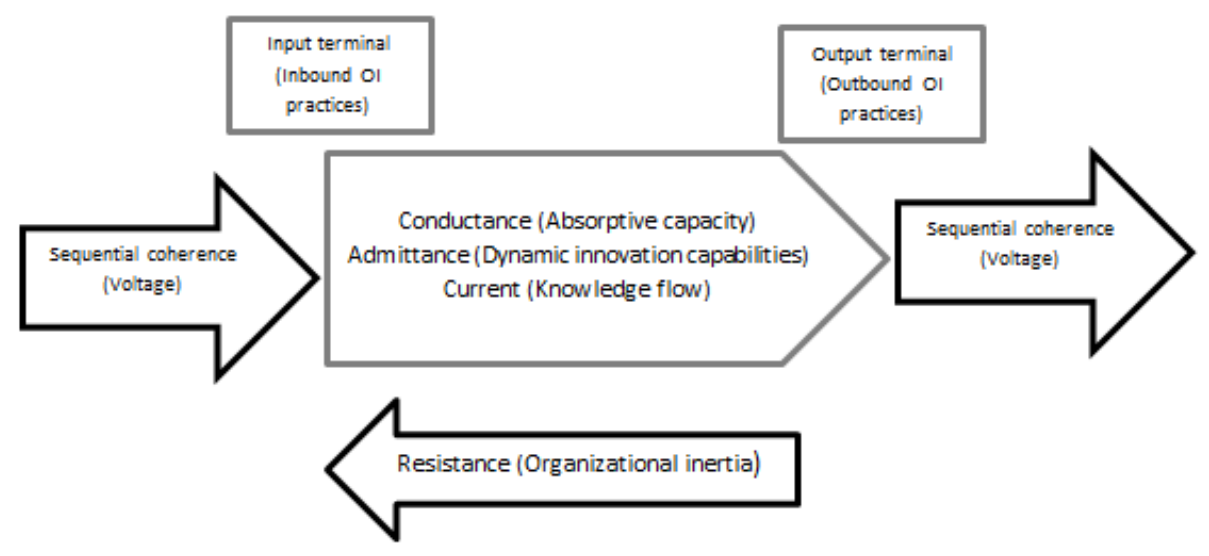

Figure 1. A novel metaphor concerning the terminology of open innovation. An electrical circuit is used in the metaphor 
Knowledge available within an external entity can be routed to a focal firm through inbound open innovation activities (Hung \& Chou, 2013; Naqshbandi et al., 2016). Similarly, knowledge inside the company can be commercialized through outbound open innovation activities (Hung \& Chou, 2013; Cassiman \& Valentini, 2016; Huizingh, 2011). Such knowledge flows correspond to the current flowing through an electrical circuit. Inbound open innovation activities and outbound open innovation activities, which are the drivers and enabling factors (Galati et al., 2016), act as the input and output terminals respectively. Inbound open innovation enables an organization to explore the external knowledge sourced from outside the firm in order to create competitive advantage (Hung \& Chou, 2013; Bianchi et al., 2011; Naqshbandi et al., 2016; Zincir \& Rus, 2019; Sivam et al., 2019; De Beule \& Van Beveren, 2019).

Open innovation is about the knowledge flows of an organization. In our metaphor, the knowledge flow in a firm corresponds to the current $(I)$ in an electrical circuit:

current $=$ knowledge flow.

Organizational inertia is another concept frequently cited and tested by researchers in the open innovation domain. Organizational inertia refers to the inertia within the organization that prevents and discourages change (Wong-MingJi \& Millette, 2002). Insufficient adaptation to changes in the environment can be detrimental to the organization (Hannan \& Freeman, 1984). In our metaphor, organizational inertia corresponds to the resistance $(R)$ of the circuit:

$$
\text { resistance }=\text { organizational inertia. }
$$

Voltage $(V)$ is the pressure from the power source of an electrical circuit that creates an electrical current by pushing charged particles, like electrons, through a conducting loop. The terms voltage and electrical potential difference are often used interchangeably. Electrical potential difference is the potential energy difference between two points in a circuit.

In our metaphor, voltage corresponds to the pressure created at the boundaries known as sequential coherence, as shown in Figure 1. Sequential coherence refers to the reciprocal result of the pushing effects induced by individuals of a teaching firm and the pulling effects induced by individuals of a learning firm that enables knowledge to flow across the boundaries of firms (Yapa et al, 2019 A). Sequential coherence is measured through the willingness and ability of the participants of teacher firm and the preparedness and ability of the participants from the student firm respectively (Yapa et al., 2019 B). Dynamic innovation capabilities are the abilities of an organization to integrate, build, and reconfigure internal and external competencies in order to meet the demands of a rapidly changing environment (Teece et al., 1997). Following the work of Zollo and Winter (2002), Cheng and Chen (2013) described dynamic innovation capabilities as those hard-to-transfer and hard-to-imitate innovation capabilities that firms use to develop, integrate, and reconfigure existing and new resources and capabilities. In our metaphor dynamic innovation capabilities correspond to admittance. Admittance $(Y)$ refers to the circuit elements' allowance of the flow of current. We see this intentional tolerance as the reason for the flexibility and robustness in the circuit in relation to accommodating fluctuations of input conditions.

Thus, in our metaphor voltage corresponds to sequential coherence.

\section{voltage $=$ sequential coherence}

The corresponding term for dynamic innovation capabilities is admittance:

$$
\text { admittance }=\text { dynamic innovation capabilities. }
$$

Absorptive capacity plays a vital role in the innovation activities of an organization (Lane et al., 2006; Cui et al., 2018). Cohen and Levinthal (1990) described absorptive capacity as the ability of an organization to recognize the value of external knowledge, assimilate it, and apply it for commercial ends. The external knowledge inflows of a firm influence innovations indirectly through absorptive capacity (De Zubielqui et al., 2016). In our metaphor, absorptive capacity corresponds to the conductivity of an electrical circuit. Conductivity $(\sigma)$ and resistance $(R)$ are the two sides of the same coin. They are inversely related. By strengthening its absorptive capacity, an organization can overcome organizational inertia (Godkin, 2010). Similarly, Cheng, and Chen (2013) use the concepts of absorptive capacity and organizational inertia to describe dynamic innovation capabilities.

The higher the voltage difference is and the better the conductivity is, the higher the current flowing through an electrical circuit is. The absorptive capacity of a firm corresponds to conductivity here. Escribano et al. (2009) argue that organizations with higher levels of absorptive capacity can manage external knowledge flows more efficiently and stimulate innovations. Absorptive capacity is a pre-condition for an organization internalizing the 
external knowledge coming through inbound open innovation activities (Kim et al., 2016; Huang et al., 2015; Spithoven, 2010). A firm's absorptive capacity determines the extent to which extramural knowledge is utilized (Cohen \& Levinthal, 1990). Thus, in our metaphor conductivity corresponds to absorptive capacity:

$$
\text { conductivity = absorptive capacity. }
$$

\section{The equation $I=V / R$ and the open innovation metaphor}

Ohm's law states that the current through a conductor between two points is directly proportionate to the voltage across the two points, provided that the resistance is constant. The equation is $I=V / R$. The metaphorical interpretation is that the knowledge flow is directly proportional to the pressure created by sequential coherence when organizational inertia remains constant.

In the literature, the relationship between absorptive capacity and organizational inertia is not well explored. Hedberg and Wolf (2003) argued that absorptive capacity can be limited by organizational inertia. It is interesting how well the new metaphor can increase our understanding of this relationship. In the metaphor, absorptive capacity corresponds to conductance and organizational inertia to resistance. In an electrical circuit, higher conductivity means lower resistance and vice versa. Correspondingly, in an organization, higher absorptive capacity means lower organizational inertia. Furthermore, higher organizational inertia, or in other words reluctance to accommodate change, can hinder the absorptive capacity of a firm.

\section{Ambidexterity in Innovation}

An ambidextrous firm is capable of striking a balance between exploring external knowledge and exploiting internal knowledge. Such firms are more likely to record superior performance compared to an organization selecting one at the expense of the other (Thushman \& O'Reilly, 1996). Although, making both inbound and outbound open innovation work for an organization simultaneously is challenging, it can ensure smooth knowledge flows, leading to better performance (Cassiman \& Valentini, 2015).

A ground path facilitated by diodes, varistors, and gas discharge tubes is a common feature in electrical circuits. With a ground path, any excessive voltage can be grounded before it damages the circuit, any connected devices, or people. How does this correspond to the open innovation setting? Too much information is harmful (Himma, 2007). It can lead to stress and fatigue among employees and the failure of the system to produce the expected results (Lee et al., 2016). Knowledge repositories, archival systems, and the discard of unnecessary information are some useful management practices that managers may use. These correspond to various types of diodes, varistors, and gas discharge tubes in the ground path of an electrical circuit.

\section{What Else Can We Learn from This Metaphor?}

Open innovation demonstrates how firms intentionally open up innovation processes in order to acquire knowledge and to collaborate (Chesbrough, 2003; Naqshbandi, 2016; Remneland-Wikhamn \& Wikhamn, 2011). Switching plays a vital role in an electrical circuit. Switching ensures the proper functionalities that are expected from the circuit. In the metaphor, switching is understood to correspond to coordination, an elementary function of managers. Coordination is defined as managing interdependencies (Malone \& Crowston, 1994; Crowston, 1997; Sinha \& Van de Ven, 2005; Slepinov et al., 2014) and this area needs more exploration in open innovation. Component compatibility and interoperability are important in building and managing electrical circuits. This corresponds to the case of managing an effective open innovation system (Maxwell, 2006; Gasser \& Palfrey, 2007; de Mattos et al., 2018).

An organization can simply act as a conductor or a super conductor in an innovation network without any returns to the organization itself. The organization simply acts as a bridge in the knowledge flow. High conductance of an electrical circuit can ensure efficient power transmission. Correspondingly, in a network of organizations, the focal firm can grasp knowledge and route it to another organization with no distortions. Is it worth the trouble? Therefore, we suggest that alignment of goals, interests, and culture between partner firms is important for better performance in open innovation. Understanding the necessity of proper alignment and coordination among each and every organization is another point emanating from the new metaphor. In addressing synergy gains and knowledge spillover in open innovation, the new metaphor can bring useful insights.

How to reduce organizational inertia is another concern in open innovation activities. The corresponding term for organizational inertia in our metaphor is resistance. The domain literature pertaining to physics and engineering suggests why resistance goes up and ways to address this, such as changing the length of the conductor, the material composition, the area of the cross section, and the temperature. This suggests to us the necessity to pay attention to the organizational structure, selection, job design, and the allocation of work in order to reduce organizational inertia. 
The resistance of metallic conductors will increase with an increase in temperature, making the conductivity decrease. In order to increase conductivity, the current flow and voltage have to be regulated. In the metaphor, temperature can be assumed to correspond to the activity level of an organization. In accordance, a higher activity level makes the place busy and heated up. Correspondingly, in the metaphor, an increase in workload may increase organizational inertia, reducing the absorptive capacity of the firm. When the motive is to see an increase in absorptive capacity, the management may attempt to influence absorptive capacity through knowledge flow, which corresponds to electric current, and aligning it with technology push and market push, which correspond to voltage.

Feedback loops are common in electrical circuits. Feedback loops are a way of ensuring the self-alignment of the system. Correspondingly, in knowledge flows, having a feedback system is essential (Rubenstein-Montano et al., 2001). Feedback systems enhance the efficiency and effectiveness of an open innovation network.

\section{Connecting the Metaphor to Innovation Performance}

In analyzing open innovation, one of the most tested dependent variables has been innovation performance (Ahn et al., 2016; Cheng et al., 2016; Belussi et al., 2010; Bianchi et al., 2015; Cassiman \& Valentini, 2016; Seyfettinoglu, 2016). Innovation performance has been measured by process and product innovations (Greco et al., 2016; Laursen \& Salter, 2006), incremental and radical innovations (Gassmann, 2006), revenue (Caputo et al., 2016; Chaston, 2013), and profits (Faems, 2010; Mazzola et al., 2016). In our metaphor, innovation performance corresponds to the power $(W)$ of an electrical circuit. The equation $W=V I$ describes the relationship between power, voltage, and electric current. Correspondingly, in our metaphor, the innovation performance of an organization is a function of two variables. Firstly, the boundary conditions created by sequential coherence that facilitate knowledge flow across the organizational boundaries. Secondly, the knowledge flow within the organization, which is influenced by absorptive capacity and organizational inertia of the organization.

What will happen if we continue to increase the admittance of an electrical circuit? For an example, let us consider replacing a $60 \mathrm{~W}$ bulb in a simple circuit with a $100 \mathrm{~W}$ bulb. The $100 \mathrm{~W}$ bulb will glow brighter than the $60 \mathrm{~W}$ bulb did. This represents an increase in performance. Will the performance keep on increasing if we keep on increasing the admittance? No, performance will eventually reach a maximum level and then performance will drop as the light bulbs or other parts of the electrical circuit cannot handle the corresponding increased current. The electrical circuit eventually completely fails. In our metaphor, admittance corresponds to dynamic innovation capabilities. Cheng and Chen (2013) have suggested that dynamic innovation capabilities show an inverted U-shaped relationship with innovation performance. These corresponding relationships provide further evidence of the effectiveness of our metaphor in creating a deeper understanding of open innovation.

\section{Future Research Opportunities}

This study is preliminary and explorative in nature. It offers an ample source for future research studies. Bogers et al. (2017) have emphasized the importance of examining the effectiveness of open innovation in terms of innovation performance and overall firm performance. How to maximize efficiency is a new topic for open innovation research (Greco et al., 2017; Bogers et al., 2019). The domains of physics and electrical engineering use a wide array of terms when measuring the efficiency and effectiveness of entities such as devices, components, and systems. We believe that our metaphor can assist future researchers exploring the topics of the efficiency and effectiveness of open innovation by using analogies in those domains.

The reconceptualization of absorptive capacity by Zahra and George (2002) introduced four dimensions: acquisition, assimilation, transformation, and exploitation. Acquisition and assimilation that attempt to leverage the firm's ability to receive and recognize external knowledge represent potential absorptive capacity. Transformation and exploitation that attempt to leverage the absorbed knowledge represent realized absorptive capacity. Existing theories and frameworks have limitations when explaining why there can be a gap between potential and realized absorptive capacities and how to bridge this gap where it exists. The new metaphor may provide us with clues regarding these issues. Another unexplained or less researched area is the mobility of knowledge across the four listed areas of absorptive capacity.

Dahlander and Gann (2010) used the term permeability in explaining different situation-dependent levels of openness in open innovation. The way of how different types of permeability - such as apparent, absolute, and intrinsic permeability - influence conductance is researched in various disciplines of science. Absorptive capacity is represented by conductance in our metaphor. It can be further studied through permeability perspectives in science by future researchers in order to bring new insights for open innovation researchers and practitioners. 


\section{Conclusion}

This article presents a metaphor concerning the terminology of open innovation. This metaphor helps both academics and practitioners in getting a deeper understanding of the terms and their relationships in this emerging field. An electrical circuit is used as the metaphor. Table 1 lists the terms used in the metaphor of an electrical circuit and their corresponding terms in open innovation. The terms are listed in alphabetical order.

Table 1. The terms used in the metaphor of an electrical circuit and their corresponding terms in open innovation. The terms are listed in alphabetical order

\begin{tabular}{|l|l|}
\hline Terms used in the metaphor of an electrical circuit & Corresponding terms in open innovation \\
\hline Admittance & Dynamic innovation capabilities \\
\hline Conductance & Absorptive capacity \\
\hline Current & Knowledge flow \\
\hline Input terminal & Inbound open innovation practices \\
\hline Output terminal & Outbound open innovation practices \\
\hline Power & Innovation performance \\
\hline Resistance & Organizational inertia \\
\hline Voltage & Sequential coherence \\
\hline
\end{tabular}

According to Hunt and Menon (1995), metaphors are theoretically rich if the source discipline has a large body of models and theories. Tourangeau and Sternberg (1982) state that a greater distance between the domains can lead to a better-quality metaphor. As our metaphor comes from the disciplines of physics and engineering, we thus deem this metaphor has good grounds for increasing our understanding of the terms used in open innovation and the relationships that the terms have.

A new metaphor can offer novel, fresh insights into the patterns of interrelationships (Hunt \& Menon, 1995), which have not been captured by extant frameworks in the open innovation domain. Readers should note that metaphors have their inherent weaknesses and limitations. However, due to the complex nature of interdependencies in open innovation (Lopez \& Carvalho, 2018) we attempted to best explain key concepts in the domain, their inter-relationships, and their impacts on innovation performance by using the metaphor of an electrical circuit. The analysis also provides some practical insights for managers.

\section{References}

Ahn, J. M., Ju, Y., Moon, T. H., Minshall, T., Probert, D., Sohn, S. Y., \& Mortara, L. (2016). Beyond absorptive capacity in open innovation process: the relationships between openness, capacities and firm performance. Technology Analysis \& Strategic Management, 28(9), 1009-1028. https://doi.org/10.1080/09537325.2016.1181737

Al-Belushi, K. I., Stead, S. M., \& Burgess, J. G. (2015). The development of marine biotechnology in Oman: Potential for capacity building through open innovation. Marine Policy, 57, 147-157. https://doi.org/10.1016/j.marpol.2015.03.001

Belussi, F., Sammarra, A., \& Sedita, S. R. (2010). Learning at the boundaries in an "Open Regional Innovation System": A focus on firms' innovation strategies in the Emilia Romagna life science industry. Research Policy, 39(6), 710-721. https://doi.org/10.1016/j.respol.2010.01.014

Bianchi, M., Croce, A., Dell'Era, C., Di Benedetto, C. A., \& Frattini, F. (2015). Organizing for inbound open innovation: How external consultants and a dedicated R\&D unit influence product innovation performance. Journal of Product Innovation Management. https://doi.org/10.1111/jpim.12302

Bogers, M., Chesbrough, H., Heaton, S., \& Teece, D. J. (2019). Strategic Management of Open Innovation: A Dynamic Capabilities Perspective. California Management Review, 62(1), 77-94. https://doi.org/10.1177/0008125619885150

Bogers, M., Zobel, A. K., Afuah, A., Almirall, E., Brunswicker, S., Dahlander, L., ... Hagedoorn, J. (2017). The open innovation research landscape: Established perspectives and emerging themes across different levels 
of analysis. Industry and Innovation, 24(1), 8-40. https://doi.org/10.1080/13662716.2016.1240068

Caputo, M., Lambert, E., Cammarano, A., Michelino, F. (2016). Exploring the impact of open innovation on firm performance. Management Decisions, 54, 1788-1812. https://doi.org/10.1108/MD-02-2015-0052

Cassiman, B., \& Valentini, G. (2015). Open innovation: Are inbound and outbound knowledge flows really complementary? Strategic Management Journal. https://doi.org/10.1002/smj.2375

Chaston, I. (2013). Independent financial advisors: open innovation and business performance. The Service Industries Journal, 33(6), 636-651. https://doi.org/10.1080/02642069.2011.622371

Cheng, C. C., \& Chen, J. S. (2013). Breakthrough innovation: the roles of dynamic innovation capabilities and open innovation activities. Journal of Business \& Industrial Marketing, 28(5), 444-454. https://doi.org/10.1108/08858621311330281

Cheng, C. C., \& Huizingh, E. K. (2014). When is open innovation beneficial? The role of strategic orientation. Journal of Product Innovation Management, 31(6), 1235-1253. https://doi.org/10.1111/jpim.12148

Cheng, C. C., Yang, C., \& Sheu, C. (2016). Effects of open innovation and knowledge-based dynamic capabilities on radical innovation: An empirical study. Journal of Engineering and Technology Management, 41, 79-91. https://doi.org/10.1016/j.jengtecman.2016.07.002

Chesbrough, H. (2003). The logic of open innovation: managing intellectual property. California Management Review, 45(3), 33-58. https://doi.org/10.1177/000812560304500301

Chesbrough, H. (2020). To recover faster from Covid-19, open up: Managerial implications from an open innovation perspective. Industrial Marketing Management. https://doi.org/10.1016/j.indmarman.2020.04.010

Chesbrough, H., \& Tucci, C. L. (2020). The Interplay between Open Innovation and Lean Startup, or, Why Large Companies are not Large Versions of Startups. https://doi.org/10.1561/111.00000013

Cohen, W. M., \& Levinthal, D. A. (1990). Absorptive capacity: A new perspective on learning and innovation. Administrative science quarterly, 128-152. https://doi.org/10.2307/2393553

Cornelissen, J. P., Oswick, C., Christensen, L. T., \& Phillips, N. (2008). Metaphor in organizational research: Context, modalities and implications for research-Introduction. Organization Studies, 29(1), 7-22. https://doi.org/10.1177/0170840607086634

Crowston, K. (1997). A coordination theory approach to organizational process design. Organization Science, 8(2), 157-175. https://doi.org/10.1287/orsc.8.2.157

Dahlander, L., \& Gann, D. M. (2010). How open is innovation? Research policy, 39(6), 699-709. https://doi.org/10.1016/j.respol.2010.01.013

De Beule, F., \& Van Beveren, I. (2019). Sources of open innovation in foreign subsidiaries: An enriched typology. International Business Review, 28(1), 135-147. https://doi.org/10.1016/j.ibusrev.2018.08.005

de Mattos, C. A., Kissimoto, K. O., \& Laurindo, F. J. B. (2018). The role of information technology for building virtual environments to integrate crowdsourcing mechanisms into the open innovation process. Technological forecasting and social change, 129, 143-153. https://doi.org/10.1016/j.techfore.2017.12.020

De Zubielqui, G. C., Jones, J., \& Lester, L. (2016). Knowledge inflow from market and science-based actors, absorptive capacity, innovation and performance - A study of SMEs. International Journal of Innovation Management, 20(06), 1650055. https://doi.org/10.1142/S1363919616500559

Escribano, A., Fosfuri, A., \& Tribó, J. A. (2009). Managing external knowledge flows: The moderating role of absorptive capacity. Research policy, 38(1), 96-105. https://doi.org/10.1016/j.respol.2008.10.022

Faems, D., De Visser, M., Andries, P., \& Van Looy, B. (2010). Technology alliance portfolios and financial performance: value-enhancing and cost-increasing effects of open innovation. Journal of Product Innovation Management, 27(6), 785-796. https://doi.org/10.1111/j.1540-5885.2010.00752.x

Galati, F., Bigliardi, B., \& Petroni, A. (2016). Open innovation in food firms: Implementation strategies, drivers and enabling factors. International Journal of Innovation Management, 20(03), 1650042. https://doi.org/10.1142/S1363919616500420

Gasser, U., \& Palfrey, J. G. (2007). Breaking down digital barriers: When and how ICT interoperability drives innovation. https://doi.org/10.2139/ssrn.1033226 
Gassmann, O. (2006). Opening up the innovation process: towards an agenda. $R \& d$ Management, 36(3), 223-228. https://doi.org/10.1111/j.1467-9310.2006.00437.x

Godkin, L. (2010). The zone of inertia: absorptive capacity and organizational change. The Learning Organization, 17(3), 196-207. https://doi.org/10.1108/09696471011034900

Greco, M., Grimaldi, M., \& Cricelli, L. (2016). An analysis of the open innovation effect on firm performance. European Management Journal, 34, 501-516. https://doi.org/10.1016/j.emj.2016.02.008

Greco, M., Locatelli, G., \& Lisi, S. (2017). Open innovation in the power \& energy sector: Bringing together government policies, companies' interests, and academic essence. Energy Policy, 104, 316-324. https://doi.org/10.1016/j.enpol.2017.01.049

Hannan, M. T., \& Freeman, J. (1984). Structural inertia and organizational change. American sociological review, 149-164. https://doi.org/10.2307/2095567

Himma, K. E. (2007). The concept of information overload: A preliminary step in understanding the nature of a harmful information-related condition. Ethics and Information Technology, 9(4), 259-272. https://doi.org/10.1007/s10676-007-9140-8

Hossain, M., \& Kauranen, I. (2016). Open innovation in SMEs: a systematic literature review. Journal of Strategy and Management, 9(1), 58-73. https://doi.org/10.1108/JSMA-08-2014-0072

Huang, F., Rice, J., \& Martin, N. (2015). Does open innovation apply to China? Exploring the contingent role of external knowledge sources and internal absorptive capacity in Chinese large firms and SMEs. Journal of Management \& Organization, 21(05), 594-613. https://doi.org/10.1017/jmo.2014.79

Huizing, E. K. R. E. (2011). Open innovation: State of the art and future perspectives. Technovation, 31, 2-9. https://doi.org/10.1016/j.technovation.2010.10.002

Hung, K. P., \& Chou, C. (2013). The impact of open innovation on firm performance: The moderating effects of internal R\&D and environmental turbulence. Technovation, 33(10), 368-380. https://doi.org/10.1016/j.technovation.2013.06.006

Hunt, S. D., \& Menon, A. (1995). Metaphors and competitive advantage: Evaluating the use of metaphors in theories of competitive strategy. Journal of Business Research, 33(2), 81-90. https://doi.org/10.1016/0148-2963(94)00057-L

Kim, B., Kim, E., \& Foss, N. J. (2016). Balancing absorptive capacity and inbound open innovation for sustained innovative performance: an attention-based view. European Management Journal, 34(1), 80-90. https://doi.org/10.1016/j.emj.2015.10.002

Laursen, K., \& Salter, A. (2006). Open for innovation: the role of openness in explaining innovation performance among UK manufacturing firms. Strategic management journal, 27(2), 131-150. https://doi.org/10.1002/smj.507

Lazzarotti, V., Manzini, R., Nosella, A., \& Pellegrini, L. (2017). Innovation ambidexterity of open firms. The role of internal relational social capital. Technology Analysis \& Strategic Management, 29(1), 105-118. https://doi.org/10.1080/09537325.2016.1210119

Lee, A. R., Son, S. M., \& Kim, K. K. (2016). Information and communication technology overload and social networking service fatigue: A stress perspective. Computers in Human Behavior, 55, 51-61. https://doi.org/10.1016/j.chb.2015.08.011

Lee, C. S., Chen, Y. C., Tsui, P. L., \& Yu, T. H. (2014). Examining the relations between open innovation climate and job satisfaction with a PLS path model. Quality \& Quantity, 48(3), 1705-1722. https://doi.org/10.1007/s11135-013-9869-6

Lopes, A. P. V. B. V. \& Carvalho, M. M. D. (2018). Evolution of the open innovation paradigm: Towards a contingency conceptual model. Technological Forecasting \& Social Change, 132, 284-298. https://doi.org/10.1016/j.techfore.2018.02.014

Malone, T. W., \& Crowston, K. (1994). The interdisciplinary study of coordination. ACM Computing Surveys (CSUR), 26(1), 87-119. https://doi.org/10.1145/174666.174668

Maxwell, E. (2006). Open standards, open source, and open innovation: Harnessing the benefits of openness. innovations, 1(3), 119-176. https://doi.org/10.1162/itgg.2006.1.3.119

Mazzola, E., Bruccoleri, M., \& Perrone, G. (2016). Open innovation and firm's performance: state of the art and 
empirical evidences from the bio-pharmaceutical industry. International Journal of Technology Management, 70(2-3), 109-134. https://doi.org/10.1504/IJTM.2016.075152

Morgan, S. E., \& Reichert, T. (1999). The message is in the metaphor: Assessing the comprehension of metaphors in advertisements. Journal of Advertising, 28(4), 1-12. https://doi.org/10.1080/00913367.1999.10673592

Naqshbandi, M. M. (2016). Managerial ties and open innovation: examining the role of absorptive capacity. Management Decision, 54(9), 2256-2276. https://doi.org/10.1108/MD-03-2016-0161

Noh, Y. (2015). Financial effects of open innovation in the manufacturing industry. Management Decision, 53(7), 1527-1544. https://doi.org/10.1108/MD-12-2014-0681

Ortony, A. (1979). Some psycholinguistic aspects of metaphor. Center for the Study of Reading Technical Report; no. 112.

Palmer, I., \& Dunford, R. (1996). Conflicting uses of metaphors: Reconceptualizing their use in the field of organizational change. Academy of Management Review, 21(3), 691-717. https://doi.org/10.5465/amr.1996.9702100312

Randhawa, K., Wilden, R., \& Hohberger, J. (2016), A bibliometric review of open innovation: setting a research agenda. Journal of Production \& Innovation Management, 33, 750-772. https://doi.org/10.1111/jpim.12312

Remneland-Wikhamn, B., \& Wikhamn, W. (2011). Open innovation climate measure: The introduction of a validated scale. Creativity and Innovation Management, 20(4), 284-295. https://doi.org/10.1111/j.1467-8691.2011.00611.x

Rubenstein-Montano, B., Liebowitz, J., Buchwalter, J., McCaw, D., Newman, B., Rebeck, K., \& Team, T. K. M. M. (2001). A systems thinking framework for knowledge management. Decision support systems, 31(1), 5-16. https://doi.org/10.1016/S0167-9236(00)00116-0

Rubera, G., Chandrasekaran, D., \& Ordanini, A. (2016). Open innovation, product portfolio innovativeness and firm performance: the dual role of new product development capabilities. Journal of the Academy of Marketing Science, 44(2), 166-184. https://doi.org/10.1007/s11747-014-0423-4

Schmitt, R. (2005). Systematic metaphor analysis as a method of qualitative research. The qualitative report, 10(2), 358-394.

Sekliuckiene, J., Sedziniauskiene, R., \& Viburys, V. (2016). Adoption of Open Innovation in the Internationalization of Knowledge Intensive Firms. Engineering Economics, 27(5), 607-617. https://doi.org/10.5755/j01.ee.27.5.15371

Seyfettinoglu, U. K. (2016). Analysis of relationships between firm performance and open innovation strategies and stages in the Turkish food and beverage industry. New Medit, 15(1), 42-53.

Sinha, K. K., \& Van de Ven, A. H. (2005). Designing work within and between organizations. Organization Science, 16(4), 389-408. https://doi.org/10.1287/orsc.1050.0130

Sivam, A., Dieguez, T., Ferreira, L. P., \& Silva, F. J. G. (2019). Key settings for successful Open Innovation Arena. Journal of Computational Design and Engineering. https://doi.org/10.1016/j.jcde.2019.03.005

Slepinov, D., Waerens, B. V., \& Johansen, J. (2014). Dynamic roles and locations of manufacturing: Imperatives of alignment and coordination with innovation. Journal of Manufacturing Technology. https://doi.org/10.1108/JMTM-10-2013-0142

Spithoven, A. (2013). Open innovation practices and innovative performances: an international comparative perspective. International Journal of Technology Management, 62(1), 1-34. https://doi.org/10.1504/IJTM.2013.053037

Spithoven, A., Clarysse, B., \& Knockaert, M. (2011). Building absorptive capacity to organize inbound open innovation in traditional industries. Technovation, 31(1), 10-21. https://doi.org/10.1016/j.technovation.2010.10.003

Teece, D. J., Pisano, G., \& Shuen, A. (1997). Dynamic capabilities and strategic management. Strategic management journal, 509-533. https://doi.org/10.1002/(SICI)1097-0266(199708)18:7<509::AID-SMJ882>3.0.CO;2-Z

Tourangeau, R., \& Sternberg, R. J. (1982). Understanding and appreciating metaphors. Cognition, 11(3), 203-244. https://doi.org/10.1016/0010-0277(82)90016-6 
Tushman, M. L., \& O'Reilly, C. A. (1996). The ambidextrous organizations: Managing evolutionary and revolutionary change. California management review, 38(4), 8-30. https://doi.org/10.2307/41165852

Walsh, J. P., Lee, Y. N., \& Nagaoka, S. (2016). Openness and innovation in the US: Collaboration form, idea generation and implementation. Research Policy, 45(8), 1660-1671. https://doi.org/10.1016/j.respol.2016.04.013

West, J., \& Gallagher, S. (2006). Challenges of open innovation: the paradox of firm investment in open-source software. $R \& D$ Management, 36(3), 319-331. https://doi.org/10.1111/j.1467-9310.2006.00436.x

Wheeler, D. (1991). Metaphors for effective thinking. Teaching decision making to adolescents, 309-327.

Wong-MingJi, D. J., \& Millette, W. R. (2002). "Dealing With the Dynamic".

Yapa, S. R., \& Senathiraja, R. (2017). In-bound open innovation: Whom to converge with and why? Proceedings of the International Conference on the Humanities and the Social Sciences (ICHSS)-2017, University of Peradeniya. ISBN 978-955-589-237-7

Yapa, S. R., Senathiraja, R., Poesche, J., \& Kauranen, I. (2019, B). Sequential Coherence: A Novel Determinant of Open Innovation Performance. American Journal of Industrial and Business Management, 9, 1781-1799. https://doi.org/10.4236/ajibm.2019.99117

Yapa, S. R., Senathiraja, R., Porsche, J., \& Kauranen, I. (2019, A). The role of Sequential Coherence in Open Innovation: A qualitative inquiry. International Conference on Business Research. University of Moratuwa, Sri Lanka

Zahra, S. A., \& George, G. (2002). Absorptive capacity: A review, reconceptualization, and extension. Academy of management review, 27(2), 185-203. https://doi.org/10.5465/amr.2002.6587995

Zincir, O., \& Rus, D. (2019). Understanding Knowledge Absorption for Inbound Open Innovation Practices: How Do Knowledge Antecedents Influence the Process? In the Role of Knowledge Transfer in Open Innovation (pp. 97-117). IGI Global. https://doi.org/10.4018/978-1-5225-5849-1.ch005

Zollo, M., \& Winter, S. G. (2002). Deliberate learning and the evolution of dynamic capabilities. Organization science, 13(3), 339-351. https://doi.org/10.1287/orsc.13.3.339.2780

\section{Copyrights}

Copyright for this article is retained by the author(s), with first publication rights granted to the journal.

This is an open-access article distributed under the terms and conditions of the Creative Commons Attribution license (http://creativecommons.org/licenses/by/4.0/). 